\title{
6th Geneva Lecture Issues for the 1990s: Perspective of a Global Insurer
}

\author{
by M. R. Greenberg*
}

I am pleased to have the opportunity to share with you some observations on the issues that will confront our industry in the 1990s. My comments will be pragmatic, and based on my own experience, as I am a practitioner, not an academician. So, while what I have to say may not fit very neatly into an overall theory of managing a global insurance business, I hope my remarks will have value based on AIG's worldwide experience.

Some of my comments will be directed specifically toward the U.S. market, which still accounts for over 40 percent of world non-life premiums. In this shrinking world, the problems, issues and trends we see in the United States are increasingly exported to other markets.

Let me start with the matter of profitability. It will be increasingly difficult, perhaps impossible, for the insurance industry to serve the needs of society, both individuals and business, if it fails to make a reasonable profit on its invested capital. This is true of any business, of course, but it is something that is sometimes difficult for state regulators and other policymakers in the United States to grasp. In addition, shareholders and corporate directors tolerated for too long failed strategies that led to inferior results in our industry.

We are all painfully aware that the financial results of most U.S. property-casualty companies have been poor for years. In 1990 alone, the U.S. industry had an underwriting loss of $\$ 21.5$ billion and a combined ratio of more than 110 . The industry has not had a combined ratio below 100 since the 1970 s. Returns on equity achieved by U.S. propertycasualty insurers have also been abysmal - less than half the return of the S\&P 500 Stock Index, which is the broadest index of major U.S. equities.

These depressing statistics suggest the industry has given up trying to achieve a profit on its basic business of underwriting, and has adopted instead a cash flow or market share mentality. This lack of underwriting discipline is all too widespread, and has created a growing gap between those focused companies with clear business strategies and those without.

* Chairman, American International Group, Inc. Lecture presented at the 18th Geneva Assembly of the Geneva Association, London, June 10, 1991. 
In these circumstances, how will our industry build its capital base, serve its clients and compete in changing world markets in the future? Shareholdcrs can be expected to supply only so much new capital, and companies that are not providing their shareholders with an above-average or at least average return on investment will have a difficult time raising much new equity capital.

Why are industry results so poor? It is tcmpting to blame external factors, and clearly the regulatory climate and competitive market forccs have had a major impact. But we cannot totally blame the regulators and the marketplace for our industry's performance. Misguided stratcgies have also played a significant role. As underwriting profits crode, the temptation has becn to become more aggressive in the investment area in order to makc up the difference. This is a failed strategy, one that has resulted in the now familiar deterioration of the quality of investment portfolios in the insurance industry. Although problems with junk bonds and commercial real estate investments are more severe in the life industry than for non-life companies, the fact remains that the entire industry's financial strength is being increasingly qucstioned by the press, government officials and the general public.

Looking to the decade ahead, 1 belicve the 1990s will be a decade of significant change. It follows that the successful companies will be those that can quickly adapt to change and take advantage of rapidly evolving world markets. To do this, companies must be structured to identify market opportunities before others do, develop the products that new markets demand, and provide the service and support that make these products competitive. Thosc companies that do this will be winners in the global marketplace. Those that do not will be left behind. I would add that service and profit are not incompatible, since only companies with financial strength and stability will have the resources to innovate and invest in new products and services.

Our industry faces a number of critical issues as we enter the 1990s. They range from dealing with the cleanup of past environmental pollution to political and social issues whose ramifications extend far beyond the insurance industry. In many ways, the insurance industry has become the "deep pocket of last resort" for society. This attitude is reflected in the U.S. legal system where damage awards have escalated out of all relation to actual harm suffered, and in our system of state guaranty funds whcre even multinational corporations can avail themselves of the "safety net" originally designed to protect individual policyholders of failed insurers.

In the case of environmental cleanup, the issue relates to liability for financing the cleanup of old hazardous waste sites. Under the U.S. Superfund program, enacted by Congress in 1980 , clcanup was to be financed by a system of first establishing liability - who sent what wastc, how much and where - and then requiring those believed to be responsible to pay for clcanup.

While this may sound reasonablc in theory, it has not worked in practice. Instead of prompt and effective cleanup, we have seen the process mired in litigation and costly administrative procedures as potentially responsible partics, termed "PRPs", have negotiated with and sued each other and their insurers in attempts to avoid liability for cleanup. Many of them, in turn, have sought to identify still others who might have contributed in some way to the presencc of waste. The result has becn predictable - dclayed cleanup and enormous legal, consulting and other costs unrclated to cleanup. According to a top U.S. governmental agency, cleaning up all of Amcrica's hazardous wastc sites could take from 30 to 60 years and cost up to $\$ 500$ billion. 
Establishing liability at Superfund sites has proven to be very difficult. Under Superfund, anyone who simply used or owned or transported waste to a site at any time could be liable for the entire cleanup bill. Since Superfund liability deals with past waste disposal, the record of users for any single site can go back 25,30 or even 40 years and can number in the hundreds. As a result, the goal of cleanup has been lost as parties have spent years in negotiations and litigation, trying to establish liability for cleanup. At some sites, more money has been spent on this exercise than on cleanup itself.

To provide a way out of this dilemma, AIG has proposed creating a broad-based, nofault financing program to replace Superfund's current retroactive liability system. Our National Environmental Trust Fund would be used exclusively for cleaning up old hazardous waste sites, without the necessity to establish site-specific liability. One way this Fund could be financed would be by adding a separate fee to commercial and industrial insurance premiums in the United States. Even a modest assessment, say two percent of premiums and an equivalent amount for self-insureds, would provide about $\$ 40$ billion over the next decade - more than enough to clean up the 1,200 highest-priority sites, without endless time and money being spent on legal debates about liability. The tough liability provisions of Superfund would still be applied to sites operating today, as would all other state and federal environmental laws designed to promote responsible waste disposal.

Given the U.S. experience, I believe there is increased worldwide awareness of the problems associated with a strict retroactive liability approach to environmental cleanup. Hopefully other nations will learn from the U.S. and adopt a more cost-effective and efficient approach. The stakes are high in Europe and elsewhere as they are in the United States, and the insurance industry must play a role in devising a solution to this problem.

Financial deregulation is another trend that crosses national borders and presents similar issues for insurance companies in the U.S. and elsewhere. The blurring of lines between financial products is occurring in the United States, where banks now seek to sell - and underwrite - insurance, even as they gain wider latitude to provide services that were once the exclusive province of Wall Street investment banking firms. The Bush Administration has recently proposed financial sector deregulation legislation. Whatever the outcome of the Congressional debates now underway on its precise provisions, the final legislation is likely to provide for greater interstate banking and removal of some of the barriers between banking, insurance and the securities business. Meanwhile, life insurance companies now market savings products which closely resemble those offered by banks, mutual funds and others.

The danger in all of this, in my view, is not that we are blurring the dividing lines between industries. Deregulation in itself is not worrisome. What is of concern is deregulation without knowledgeable management. Those who now seek to enter the insurance business are the same managers who have, in many cases, engaged in lending and investment practices that have brought their institution into severe financial difficulties. The business of underwriting insurance requires skills that I do not believe reside in commercial bank management. Nor do I think that insurance company executives are particularly skilled at making commercial loans or underwriting corporate securities.

The twin issues of regulatory reform and insurer solvency have risen to the top of the public policy agenda in the United States. The well-publicized recent insurer failures, tied to the collapse of the junk bond market and problems in commercial real estate in many 
areas of the country, have brought the insurer's basic promise into question in the public's mind. This has resulted in calls for tighter regulation of investment practices and more stringent solvency standards.

But demands for stronger balance sheets are inconsistent with the other foremost trends in the insurance industry today - state-by-state politically-mandated rate-cutting, combined with enormously high jury awards for pain and suffering and punitive damages. Until we resolve the conflict between the social goal of providing a "safety net" under every person in our society and the desire to have a functioning market economy, we will not bring rationality to the insurance industry. The right to fail is an inherent component of a market economy, as is the responsibility to be an intelligent buyer. Speaking as a commercial insurer, I resist being in the position of a two-time loser, whereby I lose business to poorly-managed companies who underprice it and then have to bail them out through the state insolvency funds when they fail. This not only makes no policy sense, but it penalizes the intelligent consumer, since in the end all buyers of insurance pay for the failures of such companies through higher premiums.

The U.S. legal environment has become a disincentive to American business. I refer not only to the insurance industry, but to manufacturers of any product or service. While there is no simple solution to what has come to be termed the "liability crisis", the movement for tort reform is gaining ground on a state-by-state basis. One thing is clear: the cost of liability insurance will be prohibitive for small business in the future if significant liability reform is not achieved. We cannot have both a market economy and a riskless society, and we must marshall the industry's resources on a worldwide basis to educate the public on the dangers of thinking there can be a universal safety net.

We do live in a shrinking world, and the trend that appears in one country today will migrate to others tomorrow. In the United States, we are in an era of consumerism. This will be increasingly apparent in the 1990s in other countries, particularly in Europe. As the single European market takes shape, there will be more competition, greater deregulation and increased demands for service. While European consumers will benefit from these trends, it will not be a painless transition. As protected markets are exposed to the demands of consumerism and greater cross-border competition, dislocations will occur as they have in the United States. It will not be easy for some to accept the right to fail. How these forces will play out is not yet clear, but I believe the trends are positive.

I would like to close by citing briefly a number of key trends I see as we enter the final decade of this century. First, in the United States, we face the fact that government programs and regulations have failed us in many important areas. The savings-and-loan debacle, the problems in our banking system, the financial market dislocation, the nearbankruptcy of federal financial institutions like the F.D.I.C. and the well-publicized insurer insolvencies have all contributed to weakening Americans' confidence in their institutions and financial system.

Internationally, the twin trends of nationalism and protectionism remain a real danger to the world economy. If we cannot successfully conclude the Uruguay Round and enter an era of expanding world trade and freer world markets, I fear we will sink into a situation of increased regionalism, retaliation and protectionism. While the U.S. trading position will suffer if this occurs, others stand to lose as much or more, particularly the newly- 
industrializing nations of Southeast Asia and the emerging market economies of Eastern Europe. Without the free flow of capital, ideas, products and people, and without fair market access for foreign competitors, our markets will not expand and consumers will not benefit.

With approximately 40 percent of the U.S. commercial insurance market now in alternative markets such as self-insurance, captives, and risk retention and purchasing groups, the question inevitably arises: Are we a dying industry? Not surprisingly, I do not think so. But $I$ do believe we face a challenge in recapturing the business that is abandoning us. As an industry, we find it hard to agree on even the fundamental principles of how we should do business, how we should be regulated, what financial standards we should set, what management principles we should follow. We have been passive in seeking solutions to our most difficult problems, both domestically and internationally. We often have a "not invented here" attitude about new ideas and approaches that respond to consumer demands. We seem to be content with mediocre financial results.

As a result, we should not be surprised that the insurance industry has a generally poor image. Even when we do speak out on important issues, our motives are usually suspect and it is assumed we have only our own narrow profit interests in mind. Quite frankly, when I step back and view the problems confronting our industry and then contemplate our responses, I often conclude, as did the American cartoon character, Pogo, that "I have met the enemy and it is us."

So I believe we must change. As leaders of the worldwide insurance industry, it is incumbent on us to become problem-solvers and pro-active in designing solutions to the major issues we confront. We need to get our own house in order, focus clearly on our goals and manage our companies in a responsible way. We must also take on the issues of environmental cleanup, liability reform, regulatory reform and free trade with foresight, intelligence and perseverance. We will not survive if we fail in these tasks. 